\title{
Benoît Monginot, Poétique de la contingence. Poétique, critique et théorie à partir de Mallarmé, Valéry et Reverdy
}

\section{Andrea Schellino}

\section{(2) OpenEdition \\ 1 Journals}

\section{Édition électronique}

URL : http://journals.openedition.org/studifrancesi/5396

DOI : $10.4000 /$ studifrancesi.5396

ISSN : 2427-5856

Éditeur

Rosenberg \& Sellier

\section{Édition imprimée}

Date de publication : 1 décembre 2016

Pagination : 551

ISSN : 0039-2944

\section{Référence électronique}

Andrea Schellino, "Benoît Monginot, Poétique de la contingence. Poétique, critique et théorie à partir de Mallarmé, Valéry et Reverdy ", Studi Francesi [En ligne], 180 (LX | III) | 2016, mis en ligne le 01 janvier 2017, consulté le 18 septembre 2020. URL : http://journals.openedition.org/studifrancesi/5396 ; DOI : https://doi.org/10.4000/studifrancesi.5396

Ce document a été généré automatiquement le 18 septembre 2020.

\section{cc) (†) $\odot$}

Studi Francesi è distribuita con Licenza Creative Commons Attribuzione - Non commerciale - Non opere derivate 4.0 Internazionale. 
Benoît Monginot, Poétique de la contingence. Poétique, critique et théorie à partir de Mallarmé, Valéry et Reverdy

Andrea Schellino 


\section{RÉFÉRENCE}

BENOîT MONGINOT, Poétique de la contingence. Poétique, critique et théorie à partir de Mallarmé, Valéry et Reverdy, Paris, Honoré Champion, coll. «Bibliothèque de littérature générale et comparée», 2015, 415 pp.

C'est à un exercice d'ambitieuse généralisation et d'encadrement philosophique que Benoît MONGINOT s'adonne dans sa thèse de doctorat, soutenue en 2012 à l'Université Toulouse II et publiée chez Honoré Champion en 2015. Fort de ses persuasions théoriques, l'A., au prix d'une démarche parfois réductrice, tente de démontrer le passage de la poétique romantique (qu'il définit «ontologique») à une poétique de la «contingence» chez Mallarmé, Valéry et Reverdy. Pour ce faire, il prend en considération leurs textes littéraires et critiques.

2 Selon l'A., les romantiques, même ayant fondé leur discours poétique sur un absolu, seraient porteurs d'une crise, crise que Mallarmé, Valéry et Reverdy mènent, de manière exemplaire, à ses extrêmes conséquences. Ce sont eux qui auraient ainsi mis en discussion le «lyrisme traditionnel» (p.9) et conduit la poésie à une "altération» féconde, témoignant de l'«abandon radical du paradigme romantique». Celui-ci se présente «comme une fondation ontologique du discours poétique par les revendications corrélatives d'un droit et d'un pouvoir» (p.19). Cet effondrement du vieux paradigme ouvre, selon l'A., à un nouvel humanisme, qui cultive le souci de communication et l'autonomie de l'œuvre, le «commun» et le «singulier». 